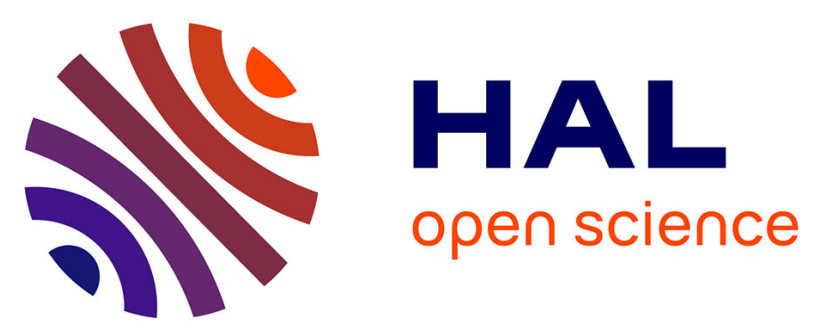

\title{
Scratching and transplanting of electro- active biofilm in fruit peeling leachate by ultrasound: re-inoculation in new microbial fuel cell for enhancement of bio- energy production and organic matter detection
}

Hakima Kebaili, Mostéfa Kameche, Christophe Innocent, Amina Benayyad, Widya Ernayati Kosimaningrum, Tewfik Sahraoui

\section{To cite this version:}

Hakima Kebaili, Mostéfa Kameche, Christophe Innocent, Amina Benayyad, Widya Ernayati Kosimaningrum, et al.. Scratching and transplanting of electro- active biofilm in fruit peeling leachate by ultrasound: re-inoculation in new microbial fuel cell for enhancement of bio- energy production and organic matter detection. Biotechnology Letters, 2020, 42 (6), pp.965 - 978. 10.1007/s10529-02002858-5 . hal-02570145

\author{
HAL Id: hal-02570145 \\ https://hal.science/hal-02570145
}

Submitted on 9 Dec 2020

HAL is a multi-disciplinary open access archive for the deposit and dissemination of scientific research documents, whether they are published or not. The documents may come from teaching and research institutions in France or abroad, or from public or private research centers.
L'archive ouverte pluridisciplinaire HAL, est destinée au dépôt et à la diffusion de documents scientifiques de niveau recherche, publiés ou non, émanant des établissements d'enseignement et de recherche français ou étrangers, des laboratoires publics ou privés. 


\section{Scratching and transplanting of electro-active biofilm}

6 Hakima Kebaili - Mostefa Kameche - Christophe Innocent • Amina Benayyad •

7 Widya Ernayati Kosimaningrum • Tewfik Sahraoui

8 Received: 25 September 2019/Accepted: 29 February 2020

9 (c) Springer Nature B.V. 2020

\section{Abstract}

11 Objective An electro-active biofilm of Fruit Peeling

12 (FP) leachate was formed onto the Carbon Felt (CF)

13 bio-anode in a Microbial Fuel Cell (MFC), after

14 functioning for a long time. The electro active-biofilm

15 thus formed was then scratched by ultrasound and re-

16 inoculated in a new leachate to be transplanted onto

17 the bio-anode. This procedure allowed the microbial

18 electron charge transfer and therefore the enhance-

19 ment of the bio-energy production of the fuel cell.

20 Results By using the repetitive mechanical biofilm

21 removal, re-suspension and electrochemically facili-

22 tated biofilm formation, the voltage was substantially

23 increased. In effect, the voltage of the 1 st $\mathrm{G}$ of biofilm,

24 rose gradually and reached its maximum value of

H. Kebaili · M. Kameche $(\bowtie) \cdot$ A. Benayyad

Laboratory of Physico-Chemistry of Materials, Catalysis

and Environment, University of Sciences and Technology

of Oran, Mohammed-Boudiaf, Oran, Algeria

e-mail: kameche@hotmail.com

mostefa.kameche@univ-usto.dz

H. Kebaili

e-mail: hakima.kebaili@univ-usto.dz;

kebailihakima@gmail.com

A. Benayyad

e-mail: benayyad1amina@gmail.com

H. Kebaili - M. Kameche · C. Innocent

W. E. Kosimaningrum

European Institute of Membranes,

University of Montpellier, Montpellier, France

e-mail: christophe.innocent@umontpellier.fr
$65 \mathrm{mV}$ after 10 days. Whilst the 2nd generation allowed to obtain the maximum voltage $276 \mathrm{mV}$ and without any lag time. The DCO abatement using the 1 st $\mathrm{G}$ biofilm was $68 \%$ greater than the 3 rd G $26 \%$. Besides, the electrochemical impedance spectroscopy characterization and cyclic voltammetry of bio-anode with 2 nd $\mathrm{G}$ biofilm confirmed the ability of electroactive biofilm formation on a new support. The biofilm transplanted showed thus greater kinetic performance, with reduced lag time demonstrating the interest of the selection that took place during the formation of successive biofilms.

Conclusions Despite the transplantation of the electro-active biofilm onto the bio-anode, the MFC still

W. E. Kosimaningrum

e-mail: widya_ernayati@yahoo.com

W. E. Kosimaningrum

Analytical Chemistry Division, Faculty of Mathematics and Natural Science, Institute of Technology Bandung, Bandung, Indonesia

T. Sahraoui

Laboratory of Electronic Microscopy and Materials Science, University of Sciences and Technology of Oran, Mohammed-Boudiaf, Oran, Algeria e-mail: sahraoui_tewfik1@yahoo.fr

\begin{tabular}{|c|c|c|c|c|}
\hline & Journal : Medium 10529 & Dispatch & 4-3-2020 & Pages: 14 \\
\hline & Article No. : $\mathbf{2 8 5 8}$ & $\square \quad \mathrm{LE}$ & & $\square \quad$ TYPESET \\
\hline & MS Code : BILE-D-19-00805R1 & $V_{\mathrm{CP}}$ & & $\checkmark$ DISK \\
\hline
\end{tabular}




\section{Abbreviations}

46
47
48
49
50

50
51

52

53

54

G-MFC

\section{Introduction}

produced relatively lower power output. Nevertheless, it has been tested successfully for monitoring and detecting the oxidation of sodium acetate substrate in the very wide concentration range $0.0025-35 \mathrm{~g} / \mathrm{l}$.

Keywords Carbon felt - Microbial fuel cell . Electroactive bio-film $\cdot$ Scratching-transplantation . Acetate detection

CF Carbon felt

CG Carbon graphite

GS Garden soil

GS-MFC Garden soil microbial fuel cell

FP Fruit peeling

FP-MFC Fruit peeling microbial fuel cell

1st First generation microbial fuel cell

1st $\mathrm{G} \quad$ First generation biofilm

2nd G Second generation biofilm (re-inoculated biofilm)

3rd G Third generation biofilm (re-inoculated biofilm)

MFC Microbial fuel cell

SS Stainless steel

Gs Generations

Owing to preservation of environment, industrial wastewaters that contain a great deal of organic matter, require stronger treatment (Mathuriya and Sharma 2009). In general, managers of industrial units choose the promising low cost technology of Microbial Fuel Cells (MFCs), for the treatment of their effluents (Huang and Logan 2008). These innovative electrochemical devices, convert organic wastes into electricity by oxidation (Tingry et al. 2013).

A MFC consists of two compartments (anodic and cathodic) separated by a cation exchange membrane. In the anodic compartment, the micro-organisms form the biofilm that oxidises the organic matter, known as biocatalyst (Santoro et al. 2017). Whilst, the cathodic compartment uses metal or nano-particles catalysts such as platinum, nickel, etc...., to reduce oxygen. Moreover, these devices need rich environment of great microbial diversity that can convert different organic compounds into sustainable and renewable energy.

Performance optimisation of MFC for wastes treatment and sustainable clean energy generation was investigated to make easier the commercialisation of this new technology (Sedighi et al. 2018). Amongst the innovative applications utilizing MFCs, we can cite the treatment of domestic wastewaters (Puig et al. 2011), the reduction of sludge produced by biological treatment (Kim et al. 2007), treatment of diary industrial effluent (Manohar et al. 2008), and more recently biotreatment of vinasse (Ottoni et al. 2019), removal of salts and elimination of heavy metals traces from wastewater (Champavert et al. 2017; Yahiaoui et al. 2020).

Upon the oxidation of organic matter by biofilm (bio-catalyst), three mechanisms between the bacterial population and electrodes, can occur: Direct transfer using cytochromes (Holmes et al. 2004; Cheng et al. 2006; Fapetu et al. 2016); indirect transfer using mediators either exogen or endogen, such as dyes (Nam and Park 1999) and phenazines (Rabaey et al. 2004) and finally electron transfer by means of nanowires (Gorby et al. 2006).

The biofilm formation mechanisms in electro active microorganisms leading to improved electrocatalytic rates for applications in bioelectrochemical systems, were addressed (Angelaalincy et al. 2018). The screening of sediment and wastewater samples to be used as anolytes in a MFC for microbial electron transfer activity, was recently investigated (Aiyer et al. 2019). The inoculation of a reactor with a scraped-off biofilm collected from a running MFC, improved the electrochemical performance of the new biofilm with respect to that was used as inoculum (Cheng et al. 2011).The successive scratching and re-inoculation steps using lower polarisation potentials, showed an increase in current density using paper waste MFC (Ketep et al. 2013).The consecutive selection and acclimatization of wastewater inoculum based, mixed culture microbial biofilms demonstrated an alternative biofilm removal, re-suspension and electrochemically facilitated biofilm formation.

It was shown that the bio-electrocatalytic current density of the secondary biofilm formation was much greater than a primary biofilm in a MFC (Liu et al. 2008). Furthermore, it has been demonstrated that once a biofilm was formed on a given anode (1st G),

\begin{tabular}{|l|lll|}
\hline & Journal : Medium 10529 & Dispatch : 4-3-2020 & Pages : 14 \\
Article No. : 2858 & $\square$ LE & $\square$ TYPESET \\
MS Code : BILE-D-19-00805R1 & $\checkmark$ CP & $\checkmark$ DISK \\
\hline
\end{tabular}




\section{Experimental}

\section{Inoculum and microbial fuel cell}

then was transferred to a new sterile leachate and made in contact with a new electrode support, it continued to grow allowing the formation of the 2nd G (Rivalland et al. 2015). Moreover, the biofilm transfer can be achieved by suspension of the support-electrode in buffered solution, handshaking and scraping of any remaining biofilm (Kim et al. 2014).

In view of this bibliography, we followed the scratching/transplanting method utilized by Ketep et al. (2013) using two different backgrounds: garden soil and natural fruit peeling leachates, for comparing and testing the advantage of biofilm re-inoculation. In effect, we tested the benefits of re-inoculation of bacterial biofilm formed on electrode surfaces using fuel cell device without prior polarization of bioanode. The purpose of the present paper was to perform the scratching/re-inoculation of bacterial biofilm, for increasing bio-energy of MFC and oxidizing organic matter contained in wastewater. We characterized the three successive biofilm generations by Scanning Electronic Microscopy (SEM), Cyclic Voltammetry (CV) and Electrochemical Impedance Spectroscopy (EIS). Besides, despite its lower power output, we utilized this MFC for monitoring and detecting the oxidation of sodium acetate in a very concentration range. Finally, we assessed the current response of the MFC-based detector to various concentrations of substrate in the effluent.

Effluent samples were prepared from $500 \mathrm{~g}$ of Fruit Peelings (FP) mixed with potassium chloride solution $60 \mathrm{mM}$ (conductivity $=8.85 \mathrm{mS} \mathrm{cm}^{-1}$ and $\mathrm{pH} 4.8$ ). Another leachate was prepared similarly using Garden Soil (GS) (conductivity $=11.72 \mathrm{mS} \mathrm{cm}{ }^{-1}$ and $\mathrm{pH}$ 5.2). They were used without further filtration as inoculum source for microbial reactor.

As illustrated by Fig. 1a, the MFC consisted of two glass spherical half-cells $75 \mathrm{~mL}$, connected to each other by cationic exchange perfluorinated membrane (Nafion-117; Dupont, Ward Hill, MA, USA), $2 \mathrm{~cm}$ in diameter. The Carbone Felt (CF) and Stainless Steel (SS) sheet were used as bio-anode and cathode respectively. They were thus, placed inside the anolyte and catholyte of the MFC. The anolyte contained the leachate fed continuously with sodium acetate solution $(20 \mathrm{mM})$, whereas the catholyte contained potassium ferricyanide $\mathrm{K}_{3}\left[\mathrm{Fe}(\mathrm{CN})_{6}\right] 20 \mathrm{mM}$. The top end of the anolyte was tightly sealed with paraffin film to reduce oxygen penetration. Owing to polarization and in order to render the biofilm electroactive, an external resistor $(1000 \Omega)$ to complete a closed external circuit loop and Copper wires were used to conduct electrons between electrodes. The electroactive biofilm was therefore formed on the surface of the electrode within 10 days and the evolution of the cell voltage with time, was then measured with the digital voltmeter (APRILIA M890C+) placed in parallel.

\section{Scratching/transplanting biofilm}

The aim of the present investigation was to select the electro-active bio-film and to eliminate the nonelectroactive bacterial species that consumed the fuel uselessly without producing any valuable energy.

In our experiments, the successive biofilm were formed in the FP effluent which was sterilized to remove planktonic microorganisms. As a matter of fact, the primary biofilm was formed from FP leachate in running MFC. It was then scratched-off from the bioanode by ultrasound and used as inoculum in another MFC to form the secondary biofilm. Besides, in order to optimize the operating conditions for electroactive biofilm development, and stabilize the substrate, sterilized sodium acetate solution was added daily. Under this condition, the $\mathrm{pH}$ of the bulk was controlled by the evolution of the effluent itself. The experimental protocol was compared to others, for allowing the formation of the primary biofilm.

In reference to literature, we review below the previous methods so far utilized for scratching and transplanting of electro-active bio-film onto carbon carbon-based materials, which are as follows:

a-As suggested by Rivalland et al. (2015), the biofilm formed on an anode (in 1st G), it was then transferred to a new sterile leachate and made in contact with a new electrode support. It resulted in the growth of the 2 nd $\mathrm{G}$ biofilm. The same procedure was followed to form the 3rd G biofilm generation.

b-As recommended by Kim et al. (2014), and Doyle et al. (2017), the biofilm transfer can be achieved by suspension of the support-electrode in buffered solution, handshaking and scraping of any remaining biofilm.

\begin{tabular}{|l|ll|}
\hline Journal : Medium 10529 & Dispatch : 4-3-2020 & Pages : 14 \\
Article No. : 2858 & $\square$ LE & $\square$ TYPESET \\
MS Code : BILE-D-19-00805R1 & $\checkmark_{\mathrm{CP}}$ & $\checkmark$ DISK \\
\hline
\end{tabular}




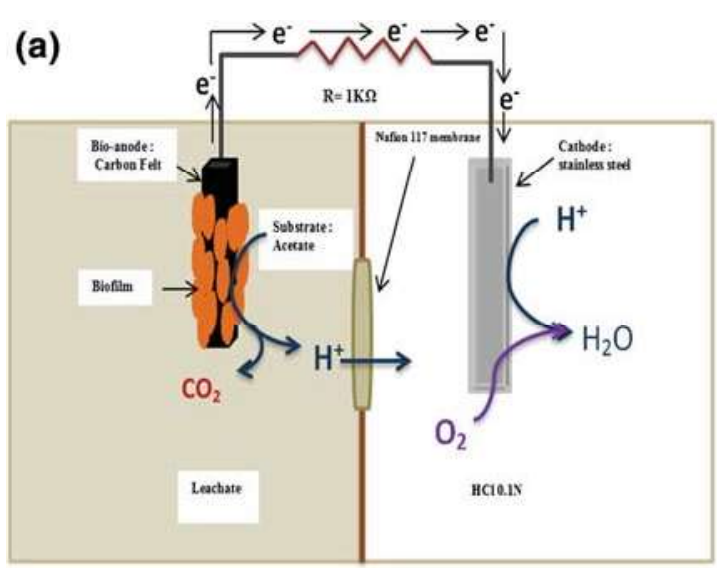

Fig. 1 a Scheme of MFC, b sonication method steps
c-As advised by Ketep et al. (2013) and Yates et al. (2017), the primary biofilm was scrapped-off from bio-anode using sonication in Ringer solution, then transferred into sterilized leachate to be re-inoculated onto a new electrode.

Accordingly, we adopted in the present work the method followed by Ketep et al. (2013). In effect, after forming the electro-active biofilm in the MFC, the electrode bearing this biofilm was subject to sonication suspended in Ringer's solution (30 ml) for $15 \mathrm{~min}$ in three replicates, $5 \mathrm{~min}$ each in order to preserve the bacterial cells already scratched. This makes it possible to recover more cells without exposing the unhooked cells to a long duration of sonication (Fig. 1b).The primary biofilm was formed onto CF bio-anode in MFC during more than ten days without supplying any electrical polarisation. The biofilms formed from the successive re-inoculations were then performed in identical experimental conditions.

The primary electroactive biofilm formed in 1 st MFC, was detached from the initial inoculated electrode by ultrasound in $30 \mathrm{ml}$ physiological sterilised Ringer solution. This volume was added to a new sterilized leachate to be inoculated and used as the anodic chamber for a new electrochemical cell called 2nd MFC. The primary biofilm were removed from the anode surface and used to inoculate a new electrochemical reactor filled with sterilized FP leachate. The new biofilm (i.e. 2nd G) was formed on the new sterilised carbon felt electrode: the same steps were followed to form 3rd G.

The scanning electron microscope JSM-6610LA was used to examine the anodic electrode surface

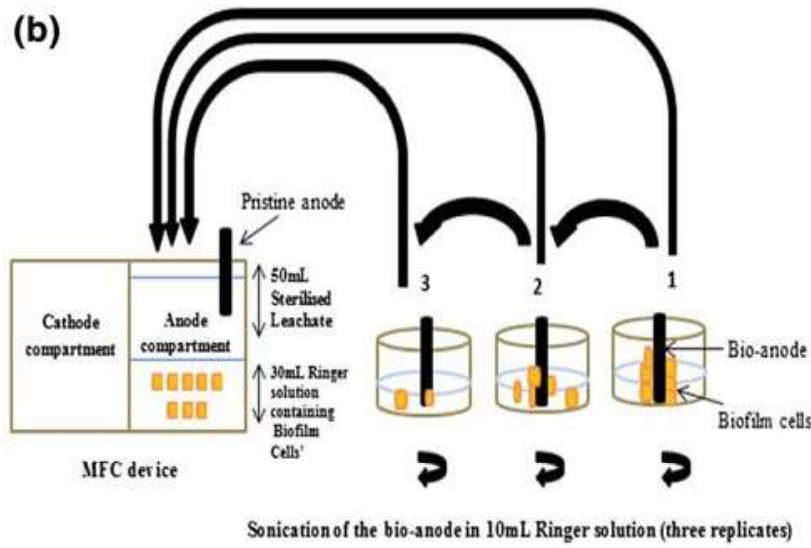

before the MFC experiment and after the biofilm reformation.

\section{Electrochemical characterisation}

The cyclic voltammetry curves were recorded at scan rate $10 \mathrm{mV} / \mathrm{s}$ and electrochemical impedance spectroscopy diagrams were recorded in range $(100 \mathrm{kHz}$ to $100 \mathrm{mHz}$ ) using the potentiostat-galvanostat (PGZ301). The temperature was maintained at $25^{\circ} \mathrm{C}$. The electrochemical glass cells of $80 \mathrm{~mL}$ were filled with FP leachate containing primary biofilm (1st G), secondary (2nd G) or tertiary biofilm (3rd G). The lid and the reactor-body were sealed with a clamping ring. The working electrodes were flat $1.27 \mathrm{~cm}$ in diameter and $5 \mathrm{~cm}$ in length CF (99\%, Alfa Aesar) screwed onto $5 \mathrm{~mm}$ diameter, $1 \mathrm{~cm}$ long graphite rods that ensured the electrical connection. The new $\mathrm{CF}$ electrodes were pre-treated by soaking in hydrochloric acid 1.0 M overnight to eliminate possible metal ion contamination, $20 \mathrm{~min}$ rinsing with distilled water (10 times) then immersed in sterilized water $48 \mathrm{~h}$ and allowed to dry in an oven $\left(50^{\circ} \mathrm{C}\right)$ at least one hour. Auxiliary electrodes were stainless steel flat cleaned by sterilization in Pasteur oven (Heraeus INSTRUMENTS Vacutherm). Potentials were controlled and expressed versus a saturated silver chloride electrode. The working electrode (i.e. bio-anode) was kept as close as possible to the reference electrode in front of the platinum auxiliary electrode.

\begin{tabular}{|l|lll|}
\hline & Journal : Medium 10529 & Dispatch : 4-3-2020 & Pages : 14 \\
& Article No. : $\mathbf{2 8 5 8}$ & $\square$ LE & $\square$ TYPESET \\
& MS Code : BILE-D-19-00805R1 & $\checkmark$ CP & $\checkmark$ DISK \\
\hline
\end{tabular}




\section{Results}

\section{Voltage evolution of MFCs}

In previous investigations, the first 1 st $\mathrm{G}$ of biofilm was obtained naturally by connecting directly the bioanode to cathode in closed circuit configuration using an electric resistance (Huang et al. 2014; Cabezas et al. 2015). Accordingly, the same procedure was, therefore followed by us to obtain the $1 \mathrm{st} \mathrm{G}$ of biofilm, where the voltage increased gradually and reached its maximum value of $65 \mathrm{mV}$ after 10 days. As for the 2nd G, the voltage started with $150 \mathrm{mV}$ without lag time and attained its highest value of $276 \mathrm{mV}$. However, the voltage of the 3rd G was lower than that of the 2 nd $\mathrm{G}$ but was still higher than the 1 st $\mathrm{G}$.

By comparing the temporal progression (Fig. 2) of MFCs using the electrodes of the 1st and 2nd Gs, the following comments may be made:

- During the first period (0-100 h), the MFC of 2nd $\mathrm{G}$ allowed a starting voltage greater than $10 \mathrm{mV}$, right up the 1st hour, which explained the rapid formation of electroactive biofilm in the presence of the 1 st $G$ biofilm scratched (tested in sterile environment and electrode). Between 100 and $200 \mathrm{~h}$, the improvement of the voltage of the 1 st $\mathrm{G}$ MFC was noticed, due to the formation of the electroactive biofilm. After $200 \mathrm{~h}$, the variations of the voltage of the two MFCs were identical which resulted in the stable formation of the electroactive biofilm on both electrodes.

- Throughout 10 days, the temporal variations of the three generations show that the FP-MFC of the 2nd

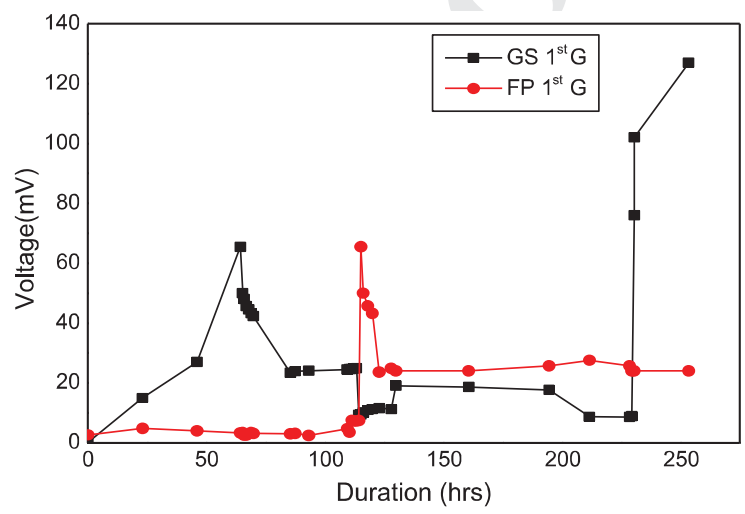

Fig. 2 Evolution voltage curves of 1st G MFC using: GS and FP leachates
$\mathrm{G}$ recorded an initial electric voltage higher than $5 \mathrm{mV}$ and a rapid progression from the second operating day (Table 1). There was an increase of the cell voltage, upon the addition of the fuel. Really, the voltage was much higher, when the medium had been changed and the fuel had been added simultaneously.

Moreover, the two MFCs of 2nd G (GS and PF) have been compared between each other. For both MFCs, an initial voltage greater than $5 \mathrm{mV}$ was observed with a rapid progression from the second operating day. In addition, during the voltage evolution, two antagonist behaviours were observed. The GS-MFC (1st G) started right up from the beginning, whilst the FP-MFC did so after 5 days. For the 2 nd G (i.e. after biofilm transplantation), the opposite occurred, showing a remarkable difference in lag time of 2 days for GS-MFC (Fig. 3).

Primary, secondary and tertiary biofilms formed in MFC

Akoğlu (2020) have recently carried out an investigation on the biofilm formation obtained from lactic acid bacteria. The biofilm was utilized advantageously and beneficially as the starter culture, for the formation of the new biofilm. On this basis, our primary biofilm collected from a MFC prototype, was removed from the anode surface by ultrasound and was then used to inoculate a new electrochemical reactor filled of sterilized FP leachate. As shown in Fig. 4, the new biofilm (2nd $G$ ) was therefore formed on the new sterilized CF electrode. The initial lag period was in contrast reduced with respect to that obviously observed with the primary biofilm; the bioenergy performances were thus amply better. Consequetively, the secondary biofilm was used to inoculate the third electrochemical reactor. The 3rd $G$ showed a

Table 1 Values of voltage (mV) of FP-MFC

\begin{tabular}{llcll}
\hline Duration (h) & Sterilized leachate & 1st G & 2nd G & 3rd G \\
\hline 33 & $<1$ & 5 & 150 & 52.2 \\
66 & $<1$ & 65 & 201.3 & 82 \\
266 & $<1$ & 20 & 276 & 220 \\
\hline
\end{tabular}

\begin{tabular}{|l|lll|}
\hline & Journal : Medium 10529 & Dispatch : 4-3-2020 & Pages : 14 \\
Article No. : 2858 & $\square$ LE & $\square$ TYPESET \\
MS Code : BILE-D-19-00805R1 & $\checkmark$ CP & $\checkmark$ DISK \\
\hline
\end{tabular}



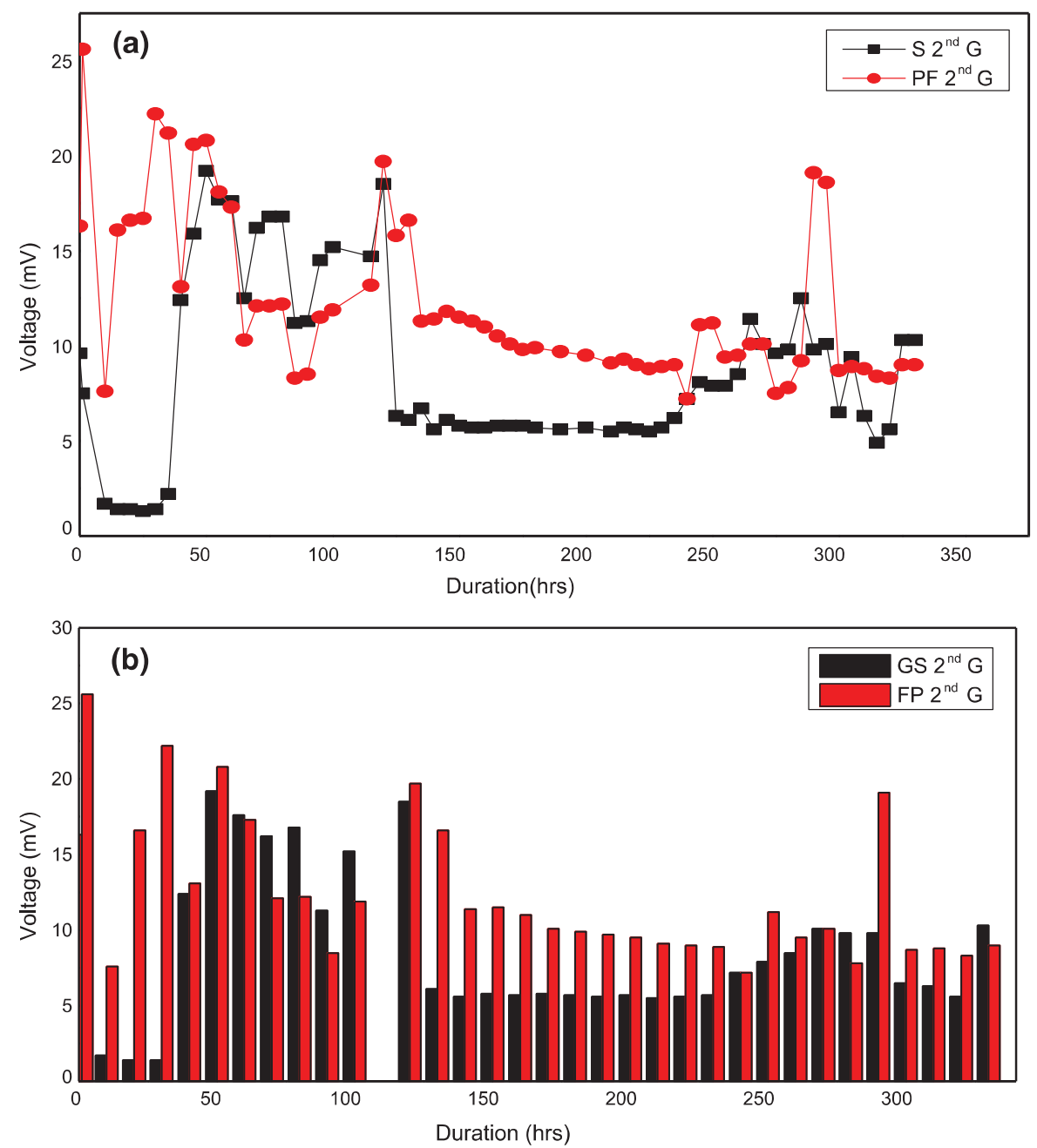

Fig. 3 Comparison between 2nd electricity generation GS and FP MFCs; a evolution curves and b bar-chart values

remarkable performance as well; it provided maximum power density about $21.77 \mathrm{~mW} \mathrm{~m}^{-2}$.

In summary, forming the primary biofilm as inoculum led to the secondary biofilm that provided the significant power density which was four times higher than that given with the primary biofilm (Fig. 5). It was besides possible to form the tertiary biofilm from the secondary biofilm as inoculum. The power density yielded with the tertiary biofilm was slightly lower than that observed with the secondary one. These results are in quite good agreement with previous investigations in the improvement of bioelectro-catalytic performance of mixed culture biofilms by consecutive electrochemical selection. A comparison of primary and secondary biofilms

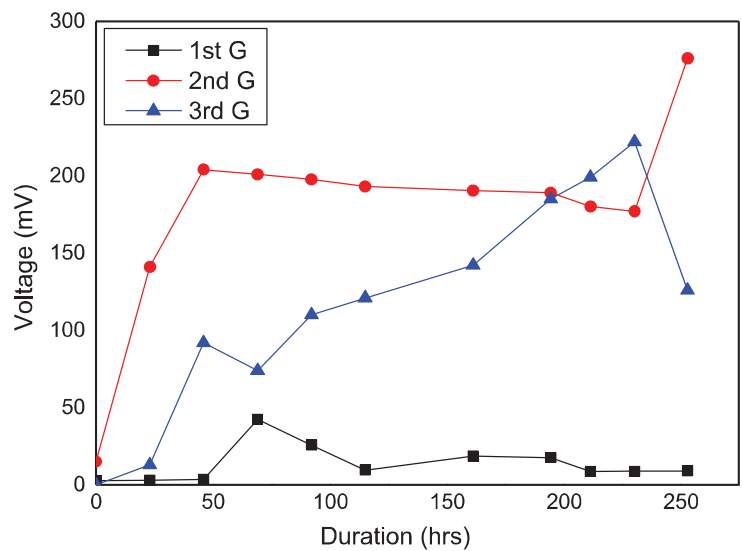

Fig. 4 Evolution voltage curves of FP-MFCs: 1st G; 2nd G and 3rd G

\begin{tabular}{|l|lll|}
\hline & Journal : Medium 10529 & Dispatch : 4-3-2020 & Pages : 14 \\
& Article No. : $\mathbf{2 8 5 8}$ & $\square$ LE & $\square$ TYPESET \\
& MS Code : BILE-D-19-00805R1 & $\checkmark$ CP & $\checkmark$ DISK \\
\hline
\end{tabular}



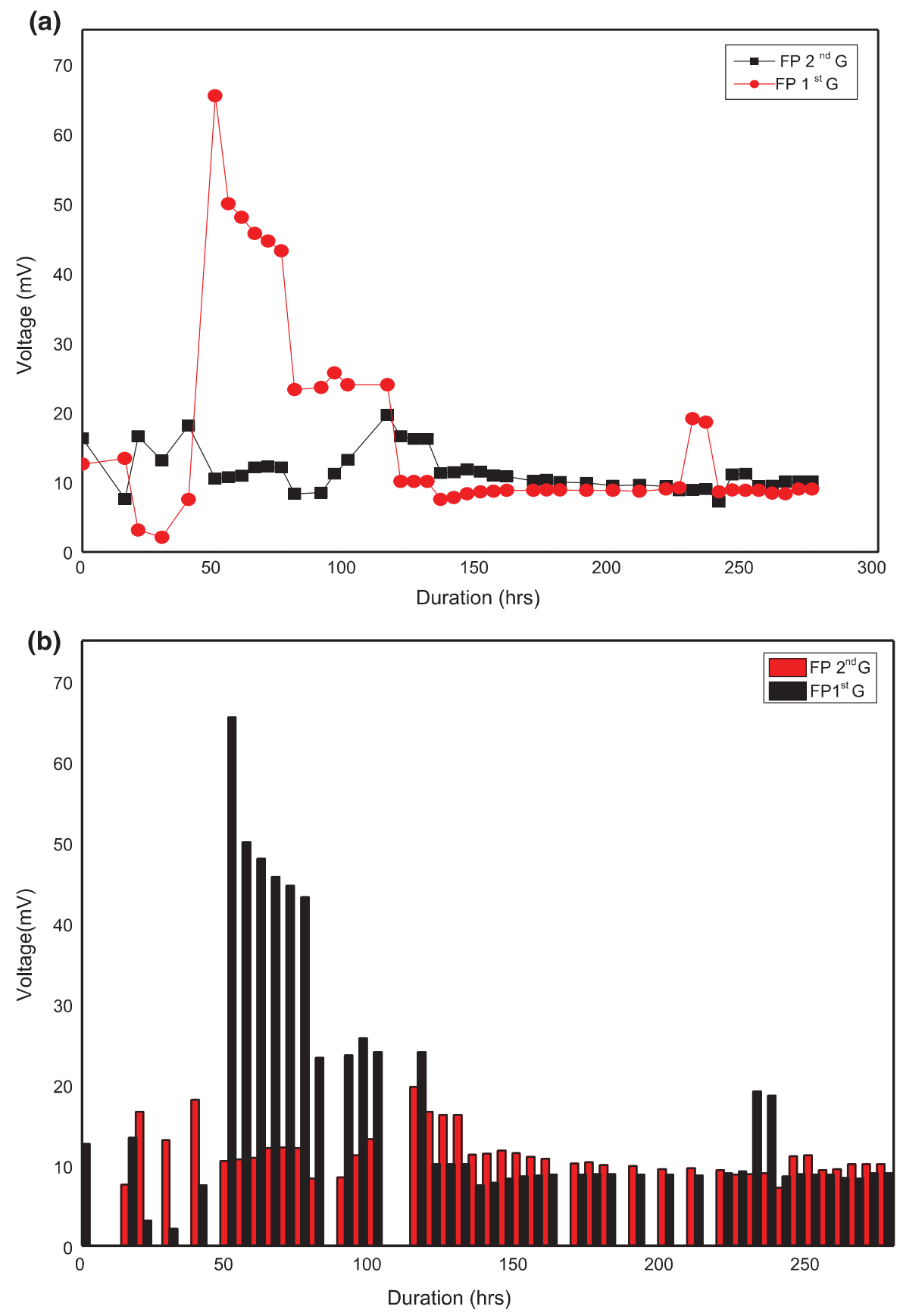

Fig. 5 Comparison between FP-MFCs of 1st and 2nd Gs; a Evolution curves and b Bar-chart values

revealed that the secondary biofilm usually exceeds the primary one (Liu et al. 2008).

Furthermore, as shown in Fig. 6, SEM images (magnification $50 \mu \mathrm{m}$ ) confirm reformation of biofilms resulting from sonication of successive FP generations: a) pristine $\mathrm{CF}$ fibres, b) biofilm of 1 st
G, c) biofilm of 2nd G, d) biofilm of 3rd G. 370 Qualitatively, the scratching/transplanting of our 371 biofilm by ultrasound seems to be in agreement with 372 the experience described by Zhao et al. (2015), where 373 it was shown that delaying polarization of carbon cloth 374 bioanode, brought about biofilm architecture that was 375

\begin{tabular}{|l|ll|}
\hline Journal : Medium 10529 & Dispatch : 4-3-2020 & Pages : 14 \\
Article No. : 2858 & $\square$ LE & $\square$ TYPESET \\
MS Code : BILE-D-19-00805R1 & $\checkmark_{\mathrm{CP}}$ & $\checkmark$ DISK \\
\hline
\end{tabular}



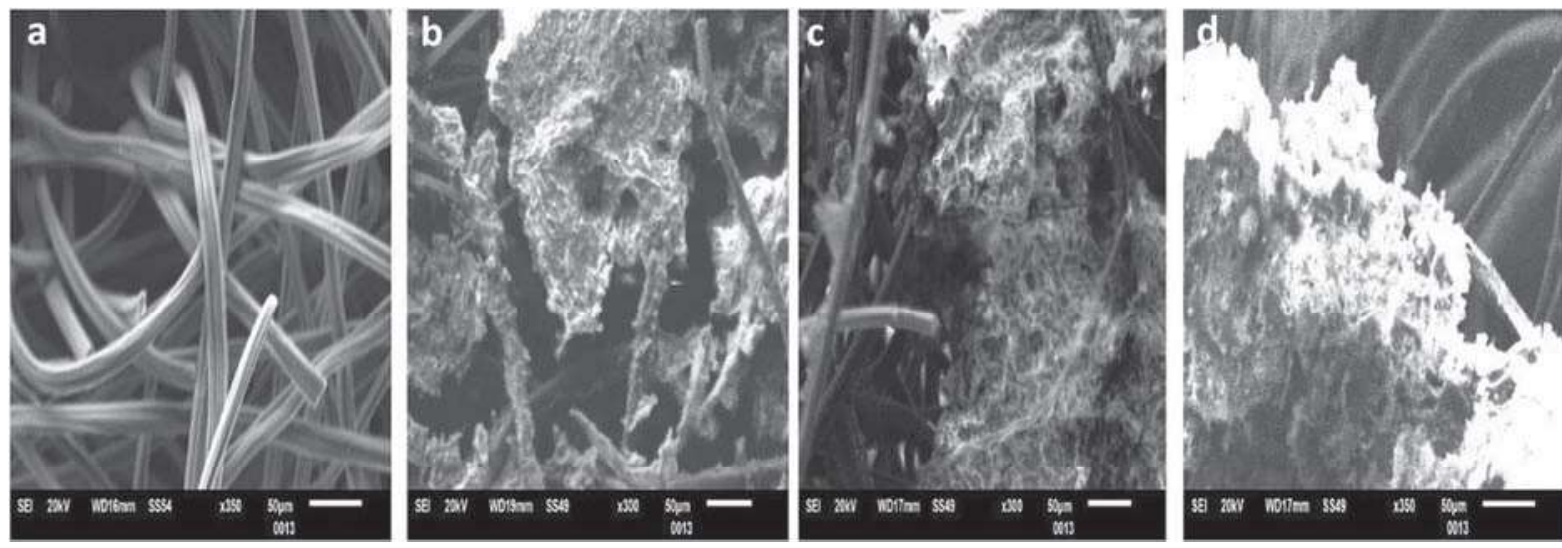

Fig. 6 SEM images (magnification $50 \mu \mathrm{m}$ ) confirm reformation of biofilms resulting from sonication of successive generations: a pristine CF; b biofilm of $1 \mathrm{st} \mathrm{G}$; $\mathbf{c}$ biofilm of $2 \mathrm{nd} \mathrm{G}$; $\mathbf{d}$ biofilm of $3 \mathrm{rd} \mathrm{G}$

more heterogeneous and thinner as compared to homogenous and thick biofilm resulting in full polarization.

\section{Electrochemical characterization}

\section{Impedance spectroscopy}

The impedance spectra of the different MFCs are represented according to the Nyquist diagram. They are represented in Fig. 7 given below, for the different electrodes (pristine, 1st G, 2nd G and 3rd G). In general, their shapes are semi-circles which intersect the axis of the real at the two points $R_{e}$ and $R_{t c}$ corresponding to the electrolyte and transfer resistances respectively. Obviously, the variations of the curves are different, reflecting the duration of operation of the MFC, in the presence of the bacterial biofilm. However, the MFC without biofilm has the highest resistance, the pristine work electrode gives a relatively higher resistance, and finally that of the 3 nd $\mathrm{G}$ has the lowest resistance due to the electro-activity of the bacterial biofilm where the electronic conduction is better. This theory is verified in the case of electrodes immersed in the juice solution of autumn peelings fruits. For GS leachate, the electrode carrying the biofilm of the $1 \mathrm{st} G$ has a higher resistance than the electrode of the 2nd G: it is assumed in this case that the electroactive biofilm has not taken enough time to rebuild itself for train the 2 nd G. In order to make it clear, a zooming has been provided inside the figure where the curves overlapped. The values of real impedance of the three generations and the pristine electrode are therefore in the following order: $\operatorname{Re}(Z)_{3 \text { rd G }}<\operatorname{Re}(Z)_{2 \text { nd G }}<\operatorname{Re}(Z)_{1 \text { st G }}<\operatorname{Re}(Z)_{\text {pristine }}$

As it is shown by the above inequalities, the thicker and fully developped the electroactive biofilm, the lower the charge transfer resistance was. The biofilmfree MFC yields the highest resistance, the sterile gives a relatively lower resistance, and finally the third generation leads to the lowest resistance due to the electro-activity of the bacterial biofilm where electronic conduction becomes much pronouced. Qualitatively, our results are comparable to those previously reported by Doyle et al. (2017), though they used polarization for the biofilm growth.

\section{Cyclic voltammetry $(\mathrm{CV})$}

The quality of the tertiary bio-anode can be assessed from CV curves recorded at day 10 , when the current was maximal. The scan rate of $10 \mathrm{mV} / \mathrm{s}$ was consequently low enough to represent the stationary characteristics of the electrode. The voltammograms recorded in the absence of substrate confirmed that the current was due to acetate oxidation. The voltammograms (Fig. 8) of the sterile electrodes show a hysteresis of the electrodes before use, due to generation of capacitive currents. As a consequence of the increase of the interface capacitance with time, the

\begin{tabular}{|l|lll|}
\hline & Journal : Medium 10529 & Dispatch : 4-3-2020 & Pages : 14 \\
& Article No. : $\mathbf{2 8 5 8}$ & $\square$ LE & $\square$ TYPESET \\
& MS Code : BILE-D-19-00805R1 & $\checkmark$ CP & $\checkmark$ DISK \\
\hline
\end{tabular}



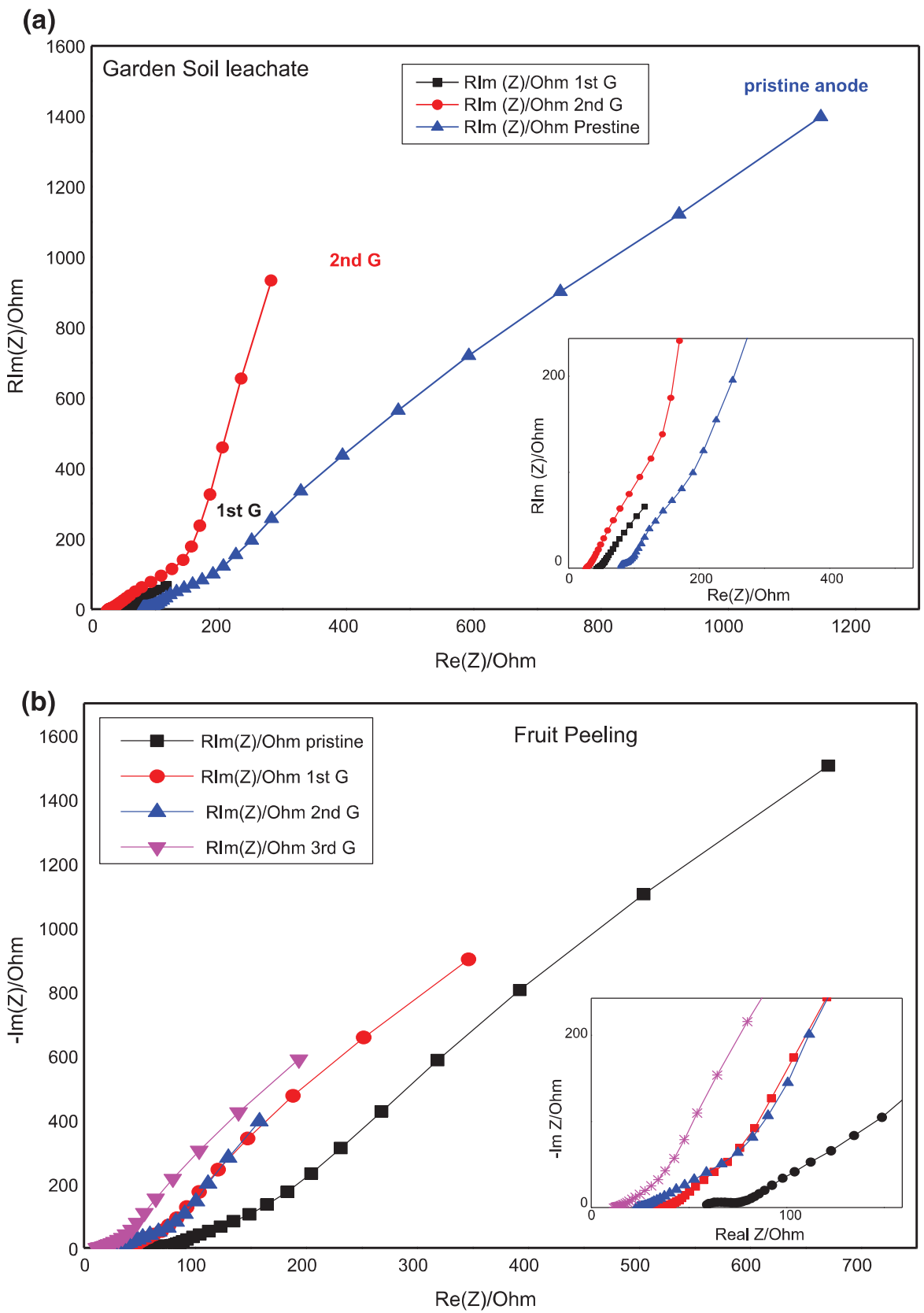

Fig. 7 a Impedance Nyquist diagram of different stages of bioanodes: pristine, 1st G and 2nd G of biofilm: GS. b Nyquist diagrams of bio-anodes inoculated with fruit peeling biofilms of:

electron transfer also increases, as indicated by the voltammograms of the electrodes of 1 st and 2 nd Gs. These observations are in accordance with the voltammograms which give clearly the redox compounds
Pristine/sterile leachate (black circle); 1st G (red circle); 2nd G and (blue inverted triangle); 3rd G (asterisk)

contained in the biofilms that can be addressed by the electrode (Fricke et al. 2008; Harnisch and Freguia 2012).

\begin{tabular}{|l|lll|}
\hline Journal : Medium 10529 & Dispatch : 4-3-2020 & Pages : 14 \\
Article No. : 2858 & $\square$ LE & $\square$ TYPESET \\
MS Code : BILE-D-19-00805R1 & $\checkmark$ CP & $\checkmark$ DISK \\
\hline
\end{tabular}




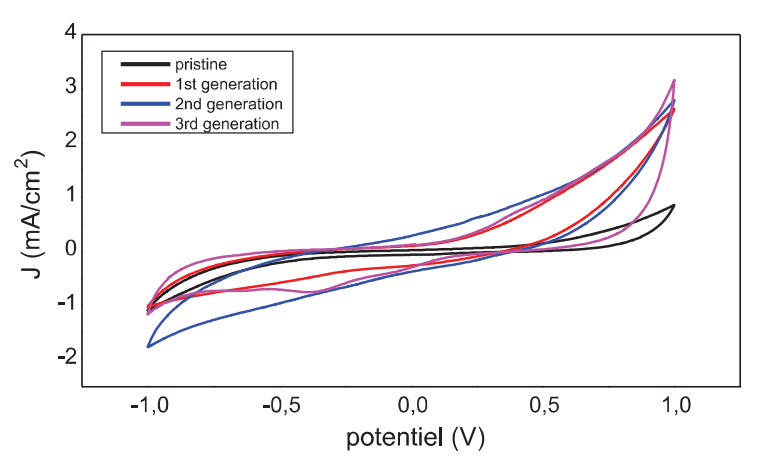

Fig. 8 Voltamogramms of bio-anodes inoculated with FP biofilms of: Pristine/sterile leachate (black line); 1 st G (red line); 2nd G (blue line); 3rd G (pink line)

Chemical oxygen demand (COD)

COD was determined for assessing the degradation of organic matter by MFC. In effect, its value for FP leachate before the treatment was about $466 \mathrm{mg} \mathrm{L}^{-1}$. After 10 days, it decreased down to 147,280 and $345 \mathrm{mg} \mathrm{L}^{-1}$ for $1 \mathrm{st}$, 2nd and 3rd G FP, respectively. The corresponding COD abatements were, therefore tabulated by using (Eq. 1).The values are summarized in Table 2. As it is illustrated, the COD abatement was thus in favour to 1st FP-MFC, while the energy production was better with 2 nd and 3 rd Gs (i.e. after transplanting). The organic matter degradation was higher with scratched biofilm from the 1 st $\mathrm{G}$ because the initial leachate contained not only the direct contact electrode biofilm but also planktonic microorganisms that helped in the COD abatement. In agreement with the results obtained recently using the MFC for the treatment of vinasse where the inoculum concentration promoted a different variation in relation to the measures of COD and power density (Ottoni et al. 2019).

COD abatement $(\%)=100 \times\left(C_{i}-C_{f}^{G}\right) / C_{i}$

where $\mathrm{C}_{\mathrm{i}}$ and $\mathrm{C}_{\mathrm{f}}^{\mathrm{G}}$ are the initial and final COD respectively.

Table 2 Values of COD abatement of FP-MFC for the three generations

\begin{tabular}{llll}
\hline Generation & 1st G & 2nd G & 3rd G \\
\hline COD abatement (\%) & 68.45 & 39.91 & 25.96 \\
\hline
\end{tabular}

Polarization and power characteristics of MFC

The characteristic curves of polarization and power of the MFC were used to evaluate the electrical performance of the cell under load. The polarization curve was obtained using different values of the resistance ranging between $10 \Omega$ and $10 \mathrm{M} \Omega$. As shown in Fig. 9, the polarization curve i.e. voltage versus current density presents three distinct regions. The first region represents the activation over voltage that results from the energy loss during the initiation of the Ox/Red reactions and electron transfer between the bacterial cell and the anodic surface. In the beginning, the MFC creates a short-circuit current density at the highest voltage. The second region shows an ohmic linear drop caused by the electrolyte. The third region displays a second over voltage that yields the maximum open-circuit current density due to the loss of concentration occurring during the diffusion phenomenon. On the other hand, the power curve i.e. power density versus current density provides the maximum energy that can be delivered by the MFC. The power density is obtained as the product of output voltage and current density. The power density versus current density provides a curve having a first ohmic linear part, which increases by reaching the maximum power point. It then falls as the current density increases. As investigated in previous work, the power density of another MFC increased in the same manner with increasing values of current density, and reached optimal values upon the addition of substrate (Zerrouki et al. 2018).

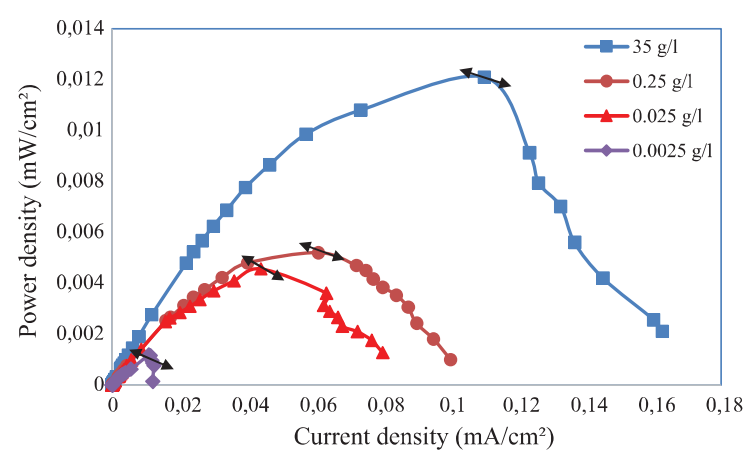

Fig. 9 Power density curves of MFCs using different concentrations of substrate (sodium acetate)

\begin{tabular}{|l|lll|}
\hline & Journal : Medium 10529 & Dispatch : 4-3-2020 & Pages : 14 \\
& Article No. : 2858 & $\square$ LE & $\square$ TYPESET \\
MS Code : BILE-D-19-00805R1 & $\checkmark$ CP & $\checkmark$ DISK \\
\hline
\end{tabular}




\section{Discussions}

Comparison between three successive bio-film generations

By using the scratched biofilm, it was possible to reform an electro-active biofilm on a new electrode in a sterilized medium. The comparison of the impedance spectra and cyclic voltamograms of the sterile electrode and the 2 nd $\mathrm{G}$ biofilm electrode confirmed the ability of the electroactive biofilm reformation on a new support. Rivalland et al. (2015) reported that the electrochemical monitoring of biofilm generations collected from French Guiana mangrove sediments, revealed the bacterial selection occurring at the anode for three distinct generations. Indeed, the first biofilm generation produced a stable current density reaching about $18 \mathrm{~A} / \mathrm{m}^{2}$ while 2 nd and 3rd Gs yielded current densities of about $10 \mathrm{~A} / \mathrm{m}^{2}$, making in evidence that the $1 \mathrm{stG}$ biofilm is more electroactive than the $2 \mathrm{nd} \mathrm{G}$ biofilm.

Besides, the importance of refreshing the medium along with the addition of the fuel, was confirmed by recorded higher voltage peaks. Ketep et al. (2014) demonstrated that the bio-anodes formed upon the addition of acetate, led to the highest current densities $\left(6 \mathrm{~A} / \mathrm{m}^{2}\right)$ but were then unable to oxidize the raw effluent efficiently $\left(0.5 \mathrm{~A} / \mathrm{m}^{2}\right)$. In contrast, the bioanodes formed without acetate addition, were fully able to oxidize the organic matter contained in the effluent, giving up to $4.5 \mathrm{~A} / \mathrm{m}^{2}$ in continuous mode. Bacterial communities showed less bacterial diversity for the acetate-fed bio-anodes compared to those formed in raw effluents. By using the biofilm off-hook, it was possible to reform an electro-active biofilm on a new sterilized electrode in a sterilized medium. Sedighi et al. (2018) investigated the relation between the power generation of MFC and the COD removal in optimised conditions. They concluded that optimising both parameters simultanously, made them compromising and therefore reducing the MFC efficiency.

\section{MFC-based bio-detector}

MFC-based biosensors are considered to be the next generation bio-sensing technology for environmental monitoring (Sun et al. 2015), in particular the inclusion of microbial activity, test of biochemical demand and detection of toxicants (Yang et al. 2015).
Although small power output of MFC constraints its application for directly operating electrical devices, great progress has been achieved in its utilization as a biosensor for monitoring of water quality and detecting of air quality (Cui et al. 2019) as well as determination of biodegradable organics (Lorant et al. 2019). So, beyond the small energy production harvested, our MFC was used also to develop a biodetector using a two-compartment cell. In the anode compartment, the biocatalyst was renewed for each sample analysis by substituting the old microbial consortium with an equal amount of fresh one. The sodium acetate substrate was utilized as a target for detection. The biofilm was involved to degrade the substrate by producing electrons to be used as source of electric energy.

During the first week, the biofilm was cultured and formed in the MFC inoculated with the initial concentration of substrate $35 \mathrm{~g} / \mathrm{l}$. At the end of the first experiment, the newly formed biofilm was well recovered as needed on the same electrode. It was then used to inoculate the new MFCs using disparate values of substrate concentrations i.e. $0.0025,0.025$ and $0.25 \mathrm{~g} / 1$ spanning more than fifteen thousands of order, to ensure the low and high detection limits. These limits were investigated by using values of maxima of power density curves that highlight the performances of the MFC.

As it is observed in Fig. 9, the peak of the maximum power seems to be proportional to the concentration of substrate consumed by the bacterial consortium. Thus the MFC can play the role of biosensor used as an organic matter detector. Besides, in order to prove this detection, the variation of the current density delivered by the MFC versus the fuel concentration (sodium acetate) is plotted. Unfortunately, it is shown to be not quite linear, because the concentration range is too wide; values are of completely different orders of magnitude ( $35 \mathrm{~g} / 1$ is 14000 times higher than $0.0025 \mathrm{~g} / \mathrm{l}$ ). Hence, a logarithmic scale plot yields a smooth straight which passes approximately through all the data points. As shown in Fig. 10, the straight line highlights the linearity of the curve in logarithmic scale.

Furthermore, the MFC with replaceable consortium could be used as a biosensor for on-line motoring of organic matter as it has been previously highlighted by Cui et al. (2019) and Sumaraj and Ghangrekar (2014). As pointed out by Sun et al. (2019), more efforts are

\begin{tabular}{|l|ll|}
\hline Journal : Medium 10529 & Dispatch : 4-3-2020 & Pages : 14 \\
Article No. : 2858 & $\square$ LE & $\square$ TYPESET \\
MS Code : BILE-D-19-00805R1 & $\checkmark_{\mathrm{CP}}$ & $\checkmark$ DISK \\
\hline
\end{tabular}




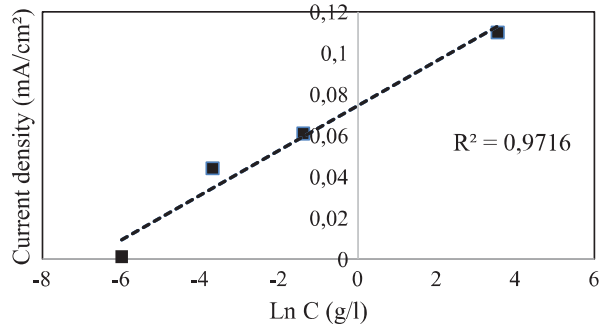

Fig. 10 Current density versus logarithm of concentration of substrate: a typical characteristic of biosensor

587

588

589

590

591

592

593

594

595

596

597

598

599

600

601

602

603

604

605

606

607

608

609

610

611

612

613

614

615

616

617

\section{Conclusions}

619 Taking our results into account, we can conclude that 620 the MFC technology is highly promising for the treatment of wastewater and the production of low bioenergy using two distinct inocula: Garden Soil and Fruit Peeling. Furthermore, in the present investigation, we have demonstrated the possibility to improve the energy production of a MFC by using different biofilm generations. The scratching of the biofilm from the electrode was achieved by ultrasound. Its reinoculation into a new leachate enhanced the energy performance of the MFC using the 2ndG biofilm. These results were confirmed by the impedance spectra and the voltammograms. In addition, the COD abatement was thus in favour to 1 stG-MFC, however, the energy production was better with 2nd \& 3rd Gs, after biofilm transplantion. Besides, the linearity of maximum current density versus concentration of substrate on logarithmic scale makes in evidence that the MFC could be used as a biosensor for the detection of the waste organic matter. It can be widely used in very wider concentration range detection for monitoring oxidation of matter, as it is the case of logarithmic detector power meter for detecting radio frequency signals.

Acknowledgements The authors are grateful to the financial support from the cooperation Tassili scheme programmme14 MDU 912 in partnership between Algeria and France.

\section{References}

Aiyer K, Vijayakumara BS (2019) Screening sediment samples used as anolytes in microbial fuel cells for microbial electron transfer activity using DREAM assay. Biotechnol Lett 41(8-9):979-985. https://doi.org/10.1007/s10529019-02704-3

Akoğlu A (2020) The effect of some environmental conditions on planktonic growth and biofilm formation by some lactic acid bacteria isolated from a local cheese in Turkey. Biotechnol Lett 42:481-492

Angelaalincy MJ, Navanietha Krishnaraj R, Shakambari G, Ashokkumar B, Kathiresan S, Varalakshmi P (2018) Biofilm engineering approaches for improving the performance of microbial fuel cells and bioelectrochemical systems. Front Energy Res 6:63

Cabezas A, Pommerenke B, Boon N, Friedrich MW (2015) Geobacter, Anaeromyxobacter and Anaerolineae populations are enriched on anodes of root exudate-driven microbial fuel cells in rice field soil. Environ Microbiol Rep 7(3):489-497

Champavert J, Mardiana U, Innocent C (2017) Bio-catalytic devices for energy production. Curr Org Chem 21(17):1702-1712. https://doi.org/10.2174/ 1385272821666170427155324

\begin{tabular}{|l|lll|}
\hline Journal : Medium 10529 & Dispatch : 4-3-2020 & Pages : 14 \\
Article No. : 2858 & $\square$ LE & $\square$ TYPESET \\
MS Code : BILE-D-19-00805R1 & $\checkmark$ CP & $\checkmark$ DISK \\
\hline
\end{tabular}


Cheng S, Liu H, Logan BE (2006) Increased power generation in a continuous flow MFC with advective flow through the porous anode and reduced electrode spacing. Environ Sci Technol 40(7):2426-2432

Cheng S, Kiely P, Logan BE (2011) Pre-acclimation of a wastewater inoculum to cellulose in an aqueous-cathode MEC improves power generation in air-cathode MFCs Bioresour Technol 102(1):367-371. https://doi.org/10. 1016/j.biortech.2010.05.083

Cui Y, Lai B, Tang X (2019) Microbial fuel cell-based biosensors. Biosensors. https://doi.org/10.3390/ bios9030092]

Doyle LE, Yung PY, Mitra SD, Wuertz S, Williams RBH, Lauro FM, Marsili E (2017) Electrochemical and genomic analysis of novel electroactive isolates obtained via potentiostatic enrichment from tropical sediment. J Power Sources 356:539-548. https://doi.org/10.1016/j.jpowsour.2017.03. 147

Fapetu S, Keshavarz T, Clements M, Kyazze G (2016) Contribution of direct electron transfer mechanisms to overall electron transfer in microbial fuel cells utilizing Shewanellaoneidesis cells as biocatalyst. Biotechnol Lett 38(9):1465-1473. https://doi.org/10.1007/s10529-016$2128-\mathrm{x}$

Fricke K, Harnisch F, Schröder U (2008) On the use of cyclic voltammetry for the study of anodic electron transfer in microbial fuel cells. Energy Environ Sci 1(1):144-147

Gorby YA, Yanina S, McLean JS, Rosso KM, Moyles D, Dohnalkova A, Beveridge TJ, Chang IS, Kim BH, Kim KS, Culley DE, Reed SB, Romine MF, Saffarini DA, Hill EA, Shi L, Elias DA, Kennedy DW, Pinchuk G, Watanabe K, Ishii S, Logan B, Nealson KH, Fredrickson JK (2006) Electrically conductive bacterial nanowires produced by Shewanella oneidensis strain MR-1 and other microorganisms. Proc Natl Acad Sci USA 103(30):11358-11363

Harnisch F, Freguia S (2012) A basic tutorial on cyclic voltammetry for the investigation of electroactive microbial biofilms. Chemistry 7(3):466-475

Huang L, Logan BE (2008) Electricity generation and treatment of paper recycling wastewater using a microbial fuel cell. Appl Microbial Biotechnol 80(2):349-355. https://doi.org/ 10.1007/s00253-008-1546-7

Huang J, Wang Z, Zhu C, Ma J, Zhang X (2014) Wu Z (2014) Identification of microbial communities in open and closed circuit bioelectrochemical MBRs by high-throughput 454 pyrosequencing. PLoS ONE 9:e93842

Holmes DE, Nicoll JS, Bond DR, Lovley DR (2004) Potential role of a novel psychrotolerant member of the family Geobacteraceae, Geopsychrobacter electrodiphilus gen. nov., sp nov. in electricity production by a marine sediment fuel cell. Appl Environ Microbiol 70:6023-6030

Ketep SF, Bergel A, Bertrand M, Achouak W, Fourest E (2013) Lowering the applied potential during successive scratching/re-inoculation improves the performance of microbial anodes for microbial fuel cells. Bioresour Technol 127:448-455. https://doi.org/10.1016/j.biortech.2012.09. 008

Ketep SF, Bergel A, Bertrand M, Barakat M, Achouak W, Fourest E (2014) Forming microbial anodes with acetate addition decreases their capability to treat raw paper mill effluent. Bioresour Technol 164:285-291. https://doi.org/ 10.1016/j.biortech.2014.04.088

Kim JR, Jung SH, Regan JM, Logan BE (2007) Electricity generation and microbial community analysis of alcohol powered microbial fuel cells. Biores Technol 98(13):2568-2577

Kim M, Gutierrez-Cacciabue D, Schriewer A, Rajal VB, Wuertz S (2014) Evaluation of detachment methods for the enumeration of Bacteroidesfragilis in sediments via propidiummonoazide quantitative PCR, in comparison with Enterococcus faecalis and Escherichia coli. J Appl Microbiol 117(5):1513-1522. https://doi.org/10.1111/jam. 12630

Liu Y, Harnisch F, Fricke K, Sietmann R, Schröder U (2008) Improvement of the anodic bioelectrocatalytic activity of mixed culture biofilms by a simple consecutive electrochemical selection procedure. Biosens Bioelectron 24(4):1006-1011. https://doi.org/10.1016/j.bios.2008.08. 001

Lorant B, Gyalai-Korpos M, Goryanin I, Tardy GM (2019) Single chamber air-cathode microbial fuel cells as biosensors for determination of biodegradable organics. Biotechnol Lett 41(4-5):555-563. https://doi.org/10.1007/ s10529-019-02668-4

Manohar A, Manohar AK, Bretschger O, Nealson KH, Mansfeld F (2008) The use of electrochemical impedance spectroscopy (EIS) in the evaluation of the electrochemical properties of a microbial fuel cell. Bioelechemistry 72:149-154. https://doi.org/10.1016/j.bioelechem.2008. 01.004

Mathuriya AS, Sharma VN (2009) Bioelectricity production from paper industry waste using a microbial fuel cell by Clostridium species. J Biochem Technol 1(2):49-52

Nam YS, Park TG (1999) Biodegradable polymeric microcellular foams by modified thermally induced phase separation method. Biomaterials 20:1783-1790

Ottoni CA, Simões MF, Santos JG, Peixoto L, Martins CR, Silva BP et al (2019) Application of microbial fuel cell technology for vinasse treatment and bioelectricity generation. Biotech Lett 41(1):107-114

Puig S, Serra M, Coma M, Balaguer MD, Colprim J (2011) Simultaneous domestic wastewater treatment and renewable energy production using microbial fuel cells (MFCs). Water Sci Technol 64(4):904-909

Rabaey K, Boon N, Siciliano SD, Verhaege M, Verstraete W (2004) Biofuel cells select for microbial consortia that selfmediate electron transfer. Appl Environ Microbiol 70(9):5373-5382

Rivalland C, Madhkour S, Salvin P, Robert F (2015) Electrochemical and microbial monitoring of multi-generational electroactive biofilms formed from mangrove sediment. J Bioelechem 106:125-132. https://doi.org/10.1016/j. bioelechem.2015.05.011

Santoro C, Arbizzani C, Erable B, Ieropoulos I (2017) Microbial fuel cells: from fundamentals to applications: a review. J Power Sources 356:225-244

Sedighi M, Aljlil SA, Alsubei MD, Ghasemi M, Mohammadi M (2018) Performance optimisation of microbial fuel cell for wastewater treatment and sustainable clean energy generation using response surface methodology. Alexandria Eng

\begin{tabular}{|l|lll|}
\hline & Journal : Medium 10529 & Dispatch : 4-3-2020 & Pages : 14 \\
Article No. : 2858 & $\square$ LE & $\square$ TYPESET \\
MS Code : BILE-D-19-00805R1 & $\checkmark$ CP & $\checkmark$ DISK \\
\hline
\end{tabular}


J 57(4):4243-4253. https://doi.org/10.1016/j.aej.2018.02. 012

Sumaraj S, Ghangrekar MM (2014) Development of microbial fuel cell as biosensor for detection of organic matter of wastewater. Recent Res Sci Technol 6(1):162-166

Sun JZ, Kingori GP, Si RW, Zhai DD, Liao ZH, Sun DZ, Zheng T, Yong YC (2015) Microbial fuel cell-based biosensors for environmental monitoring: a review. Water Sci Technol 71:801-809. https://doi.org/10.2166/wst.2015.035

Sun H, Zhang Y, Wu S, Dong R, Angelidaki I (2019) Innovative operation of microbial fuel cell-based biosensor for selective monitoring of acetate during anaerobic digestion. Sci Total Environ 655:1439-1447. https://doi.org/10.1016/j. scitotenv.2018.11.336

Tingry S, Cretin M, Innocent C (2013) Les biopiles enzymatiques pour produire de l'électricité. l'actualité chimique 373:18-25

Yahiaoui C, Kameche M, Innocent C, Khenifi A (2020) Conception of yeast microbial desalination cell: applications to dye wastewater treatment and lead removal. Chem Eng Commun. https://doi.org/10.1080/00986445.2020. 1721479
Yang H, Zhou M, Liu M, Yang W, Gu T (2015) Microbial fuel cells for biosensor applications. Biotechnol Lett 37(12):2357-2364. https://doi.org/10.1007/s10529-0151926-7

Yates MD, Ma L, Sack J, Golden JP, Strycharz-Glaven SM, Yates SR, Tender LM (2017) Microbial electrochemical energy storage and recovery in a combined electrotrophic and electrogenic biofilm. Environ Sci Technol Lett 4(9):374-379. https://doi.org/10.1021/acs.estlett.7b00335

Zhao C, Wu J, Ding Y, Wang VB, Zhang Y, Kjelleberg S, Loo JSC, Cao B, Zhang Q (2015) Hybrid conducting biofilm with built-in bacteria for high-performance microbial fuel cells. Chemelectrochem 2(2015):654-658

Zerrouki A, Kameche M, Kebaili H, Boukoussa IS, Flitti MA, Ilikti H, Innocent C (2018) An investigation on polymer ion exchange membranes used as separators in low-energy microbial fuel cells. Polym Bull 75(11):4947-4965. https:// doi.org/10.1007/s00289-018-2305-2

Publisher's Note Springer Nature remains neutral with regard to jurisdictional claims in published maps and institutional affiliations.

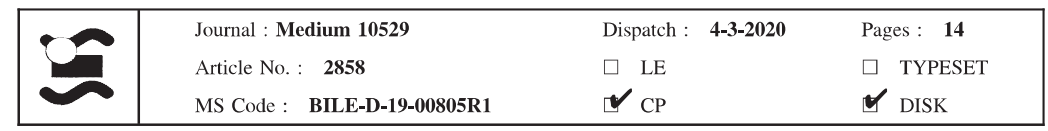

